\title{
NUMERICAL ANALYSIS OF THE ACCOUNT OF THE STAGES IN THE CALCULATION OF THE SHELL TOGETHER WITH THE SOIL MASSIF
}

\author{
Sergey B. Kosytsyn, Vladimir Y. Akulich \\ Russian University of Transport (MIIT), Moscow, RUSSIA
}

\begin{abstract}
The distinctive paper discusses the stress-strain state of a cylindrical shell with and without taking into account changes in the design model in time. The volumetric design model of the cylindrical shell and the soil massif is made. The calculation consists of several stages from the beginning of the tunnel shell construction to the end of the work. The authors analyzed the results and made appropriate recommendations.
\end{abstract}

Keywords: construction stages, soil massif, shell, finite elements, contact elements

\section{ЧИСЛЕННЫЙ АНАЛИЗ УЧЕТА СТАДИЙНОСТИ В РАСЧЕТАХ ОБОЛОЧКИ СОВМЕСТНО С МАССИВОМ ГРУНТА}

\author{
С.Б. Косицьн, В.Ю. Акулич \\ Российский университет транспорта (МИИТ), г. Москва, РОССИЯ
}

\begin{abstract}
Аннотация: в работе исследовано напряженно-деформированное состояние цилиндрической оболочки с учетом и без учета изменения расчетной модели во времени. Поставлена наследственная пространственно-временная задача с ее последовательным решением по стадиям от начала работ до окончания для цилиндрической оболочки и окружающего основания. Полученные результаты проанализированы, даны соответствующие рекомендации.
\end{abstract}

Ключевые слова: стадии строительства, грунтовый массив, оболочка, плоские и пространственные конечные элементы, контактные конечные элементы

\section{INTRODACTION}

The technology of civil, industrial and other purposes objects construction, as a rule, consists of several stages. After each stage, the stressstrain state is created in the structures, which is the initial state for the next stage and has a significant impact on the final stress-strain state of the structure. In strength calculations of structures by numerical methods, this factor is important.

Engineering calculations of building structures by numerical methods, as a rule, are performed without taking into account the initial state, the structure model is taken free from stresses and strains. However, most of the construction objects have initial and residual stress-strain state caused by each stage of their construction. As examples of such objects can be towers and masts, in the elements of which there are significant installation forces, reinforced concrete bridges with stepped concreting of the added sections, or transport tunnels, the rings of which are formed in several stages. Taking into account the initial and residual stress-strain state is important not only for new construction, but also for the repair and restoration of existing facilities. In these cases, the importance of taking into account the stress-strain state at each stage of structure construction is obvious.

In this paper, the authors consider how the construction stages affect the stress-strain state of the tunnel shell and the soil massif using numerical methods. The volumetric design model of 
the tunnel shell and the soil massif is made. The calculation consists of several stages from the beginning of the tunnel shell construction to the end of the work. The authors analyzed the results and made appropriate recommendations

\section{DETERMINATION}

THE STRESS-STRAIN STATE OF THE CYLINDRICAL SHELL AND THE SOIL MASSIF TAKING INTO ACCOUNT CHANGES DESIGN MODEL IN TIME

ANSYS software package allows creating a volumetric design model taking into account the construction stages from the beginning of the tunnel shell construction to the end of the work. ANSYS software package verified by the Russian Academy of Architecture and Construction Sciences (RAACS). Option "Birth and Death Element" of this software package allow modeling the construction stages of the considered structures. This option defines the finite elements that are to be activated or deactivated during the calculation based on some criterion: the stress state, the position in the model, etc. Deactivation, or "death", of the finite element, occurs by multiplying the stiffness of the element by a small value. The loads applied to the deactivated element are equal to zero. In addition, all load transfer mechanisms through this element are temporarily reset. When the finite element is activated, its mass, loads and stiffness return to their original values [1,2].

When modeling the construction stages in the ANSYS software package, the following features should be taken into account: it is necessary to fix the displacements or other degrees of freedom of deactivated finite elements to avoid excessive distortion. With the possible activation of these finite elements, the artificial fixation must be removed; activation and deactivation of the elements occur instantaneously, which is a step nonlinearity (similar to the status of the contact zones) that can cause problems with the numerical convergence of the solution.
This problem can be overcome by reducing the number of finite elements to be activated and deactivated at one stage of the solution; when viewing the results, deactivated elements must be excluded to avoid non-physical values [3].

The compiled volumetric design model includes a cylindrical shell and a soil massif. The diameter of the shell $D=3 \mathrm{~m}$, the thickness of the shell $t=0.3 \mathrm{~m}$, the distance between the shell and the left and right sides of the soil massif is $W=5 D$, the distance between the shell and the upper and lower sides of the soil massif is $H=$ $5 D$. The shell consists of 32 separate rings with a width of $1 \mathrm{~m}$, the soil massif at the installation site of the rings is also divided into 32 parts the activated ring replaces part of the soil massif.

The soil massif is modeled by volumetric elements. Volumetric elements consist of twenty nodes. The shell is modeled by flat elements. Flat elements consist of 4 nodes. Local coordinate systems of shell elements are co-directed for a correct display of results [4,5]. The volumetric design model is shown in Figure 1.

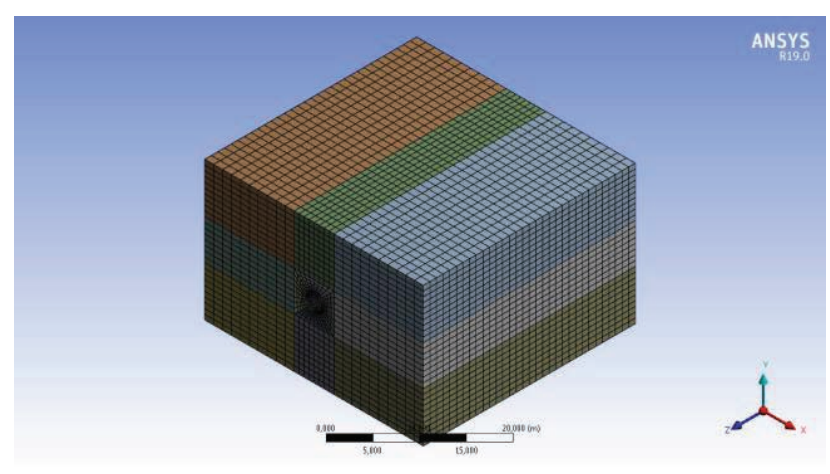

\section{Figure 1. Volumetric design model in ANSYS Mechanical.}

The material of the soil massif is presented by an elastic-plastic model of Mohr-Coulomb with the following characteristics: density $\rho-2000$ $\mathrm{kg} / \mathrm{m}^{3}$, deformation modulus $E_{\text {def }}-10 \mathrm{MPa}$, Poisson's ratio $\mu-0.30$, cohesion $C_{u}-10 \mathrm{kPa}$, friction angle $\varphi-25^{\circ}$. The material of the cylindrical shell is presented by a linear-elastic model with the following characteristics: density $\rho$ $2300 \mathrm{~kg} / \mathrm{m} 3$, elastic modulus $E-30000 \mathrm{MPa}$, 
Poisson's ratio $\mu-0.20$. These material models require a physically nonlinear calculation.

The soil massif has constraint on the side faces and on the bottom face. The load consists of the own weight of the soil massif and the shell.

In addition, there is a gap between the shell and the soil massif in the design model, which takes into account the influence of a slurry shield during the construction of the cylindrical shell. Special contact elements CONTAxxx and TARGExxx provide contact interaction between the shell and the soil massif. These elements are located on the surface of the soil massif and the cylindrical shell.

The type of contact nonlinearity is a status change. The contact status (open or closed) determines the stiffness of the system. Contact interaction occurs when the nodes of the bodies come close to a certain distance, which is called "Pinball Radius". Modeling contact interaction begins with search nodes of bodies that are close to each other. The search can be carried out through the element integration points to ensure increased accuracy [6,7]. The search algorithm for contacting nodes causes high computational complexity, so the search area can be limited. To do this, on the required surface create a contact interface of two types: contact and target.

The next algorithm stage uses the contact and the target areas to calculate the interaction forces of the bodies. The contact forces are usually determined using a method called "Penalty method". This method uses the possibility of surface nodes interpenetration by a small value. The interaction forces $F_{\text {contact }}$ depend on the penetration value and the contact stiffness. These forces are applied only to the contact surface and cause its deformation, which reduces the penetration of the surfaces $[8,9]$. In addition, when determining the penetration value, the thickness of the cylindrical shell is taken into account.

The calculation was done geometrically, structurally and physically nonlinear statement. Constructive nonlinearity appears as a result of changes in the model during its deformation, for example, changing the status of the elements constraints, the "birth" and "death" elements and so on. Constructive nonlinearity should be taken into account when modeling objects in the process of installation and dismantling, when new connections are created; when changing the loading mode or when constraints are turned off $[10,11]$.

There are six design cases in the research work that allows determining the effect of taking into account changes in the design model in time on the stress-strain state of the cylindrical shell. The first design case consists of 33 stages of determining the stress-strain state of the cylindrical shell and the soil massif: the first (zero) stage calculates the natural state of the soil massif without the shell, the next 32 stages calculate the stress-strain state of the model after activating each individual ring of the shell and deactivating part of the soil massif. The second design case consists of 17 stages, as not one, but two rings of the shell are activated in one stage. Thus, the number of rings activated in one stage doubled in each case. There are design cases with $32,16,8,4,2$ and 1 stages of calculation (first stage (zero) calculated the natural state of the soil massif in each design case).

According to the obtained results, the authors carried out a comparative analysis of the equivalent stresses according to the IV strength theory (von Mises) of the cylindrical shell for 1, 4, 8, $12,16,20,24,28$ and 32 rings of cylindrical shell. The stress curves of the cylindrical shell rings depending on the number of stages in the design case are shown in Figures $2-10$.

It can be seen from the chart that the maximum stresses values of the six design cases are markedly different. Note that in the interval from 4 to 28 ring, starting with the design case, which has 8 stages, a further increase in the number of stages did not lead to significant changes in the maximum stresses values. It is also seen from the chart that the stresses in the first ring of the shell grow significantly in going from the 8stage design case to the 16 and 32-stage design cases. The stresses in the last ring of the shell reduces significantly in going from the 8 -stage design case to the 16 and 32-stage design cases. 
Numerical Analysis of the Account of the Stages in the Calculation of the Shell Together with the Soil Massif

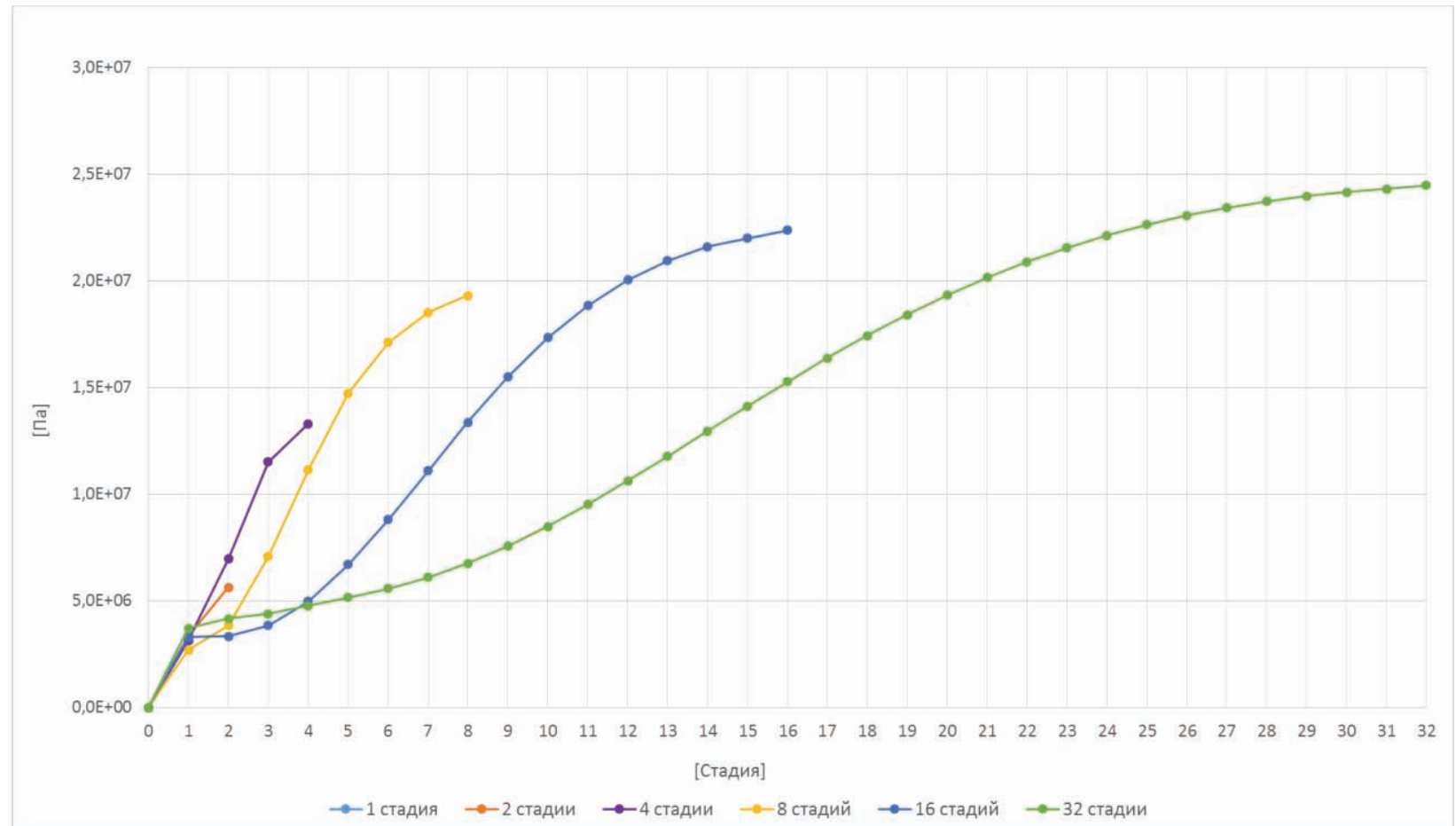

Figure 2. The maximum equivalent stresses according to the IV strength theory (von Mises) of 01 ring of the shell.

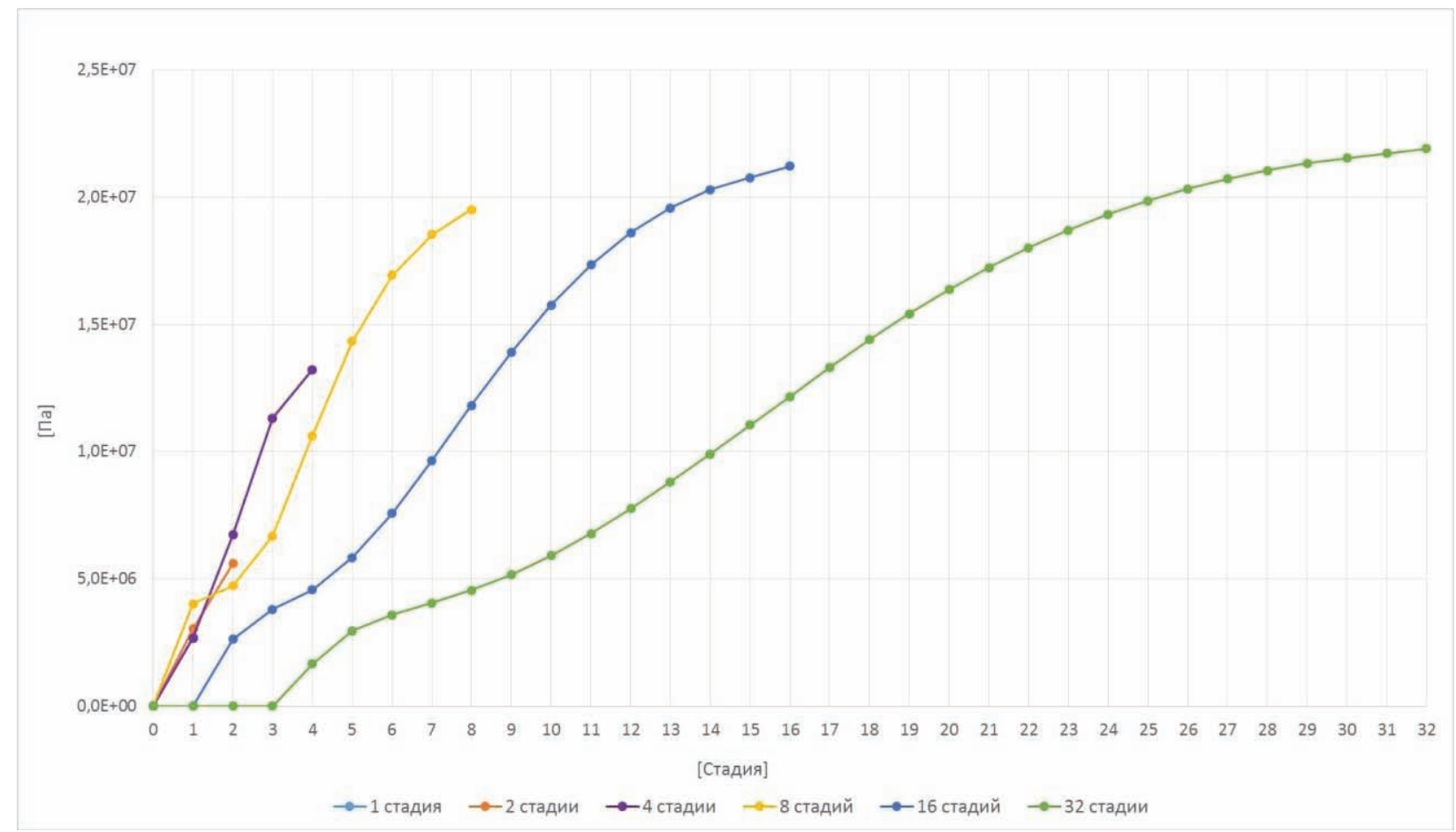

Figure 3. The maximum equivalent stresses according to the IV strength theory (von Mises) of 04 ring of the shell. 


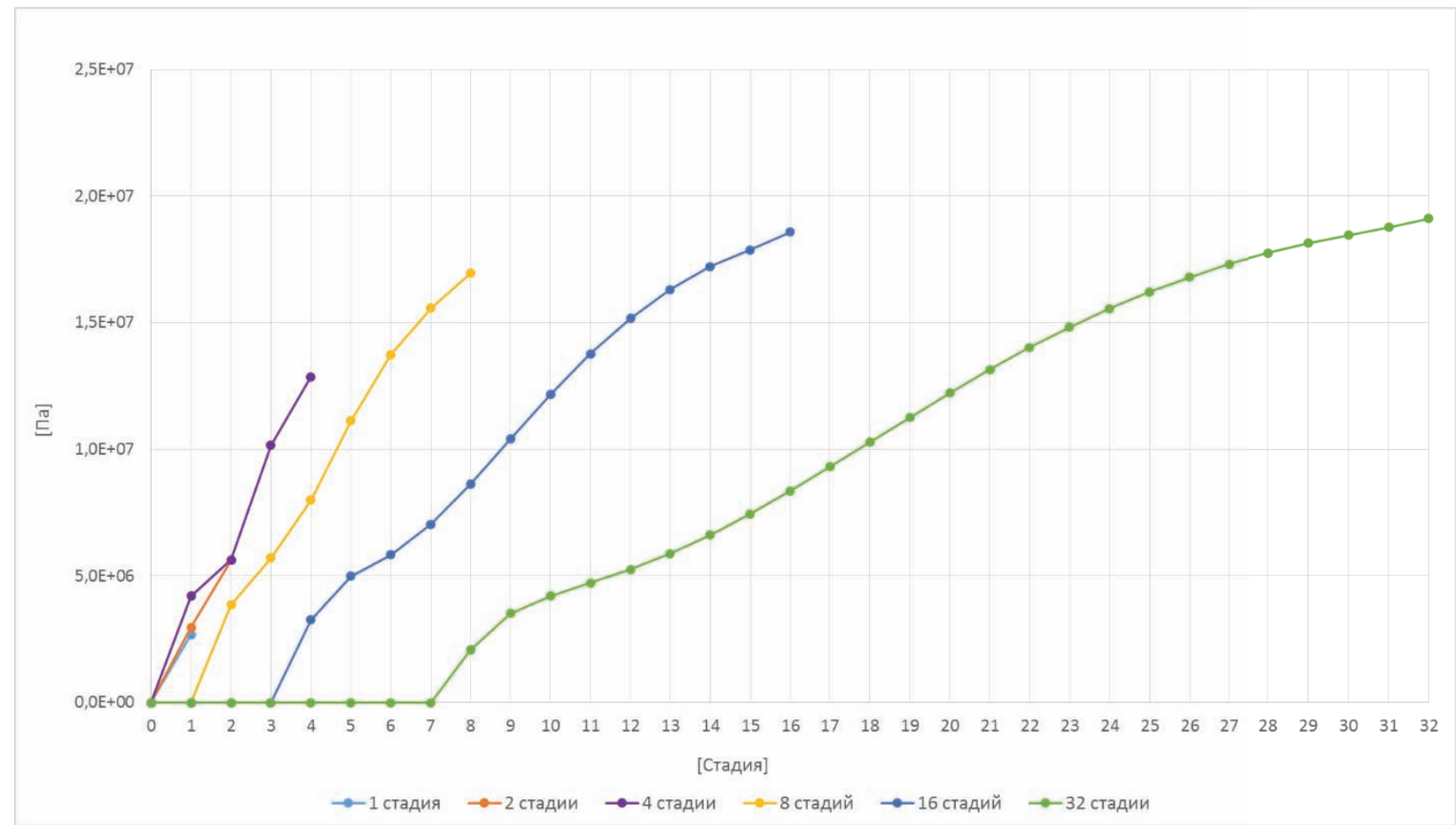

Figure 4. The maximum equivalent stresses according to the IV strength theory (von Mises) of 08 ring of the shell.

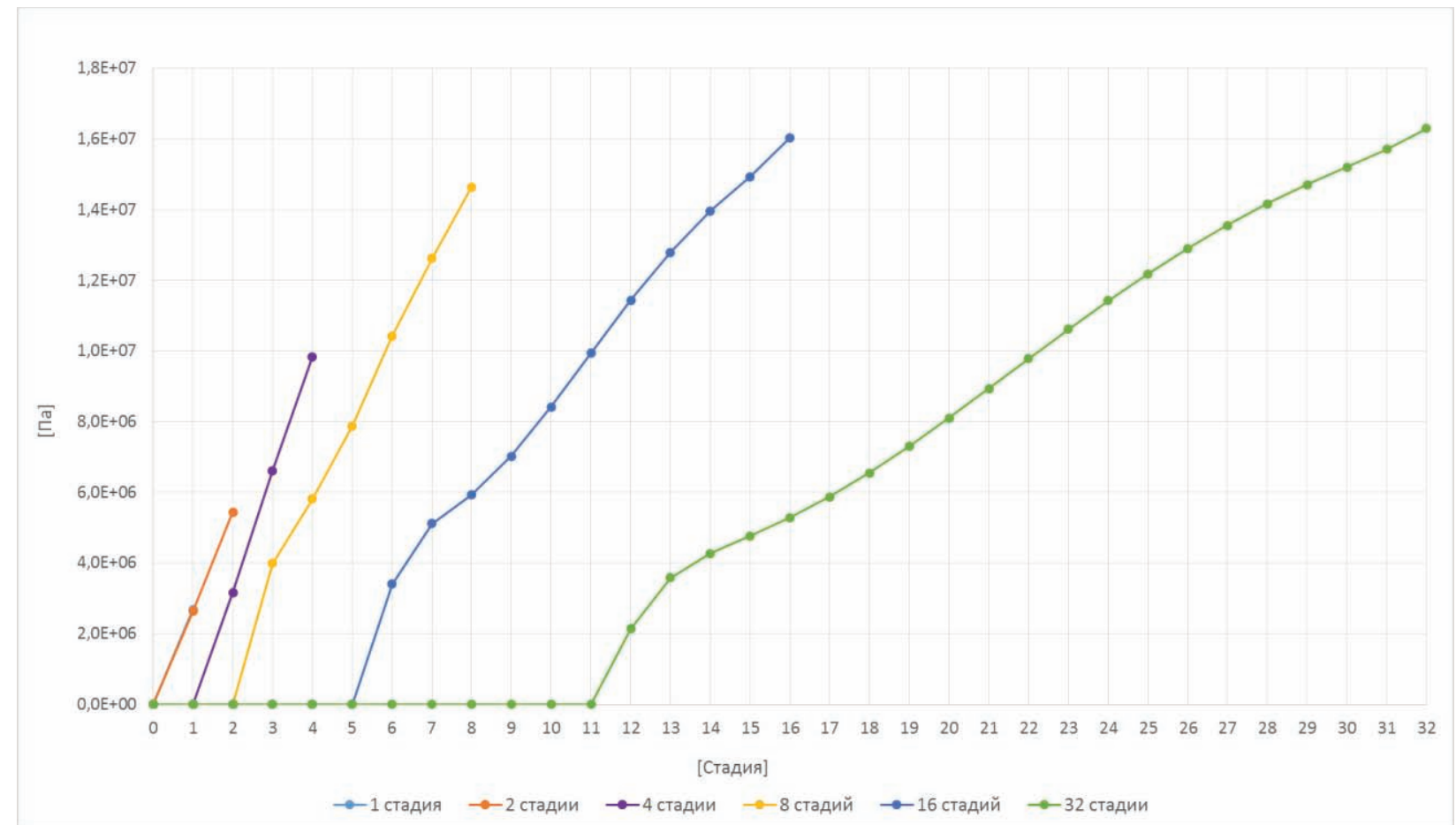

Figure 5. The maximum equivalent stresses according to the IV strength theory (von Mises) of 12 ring of the shell. 


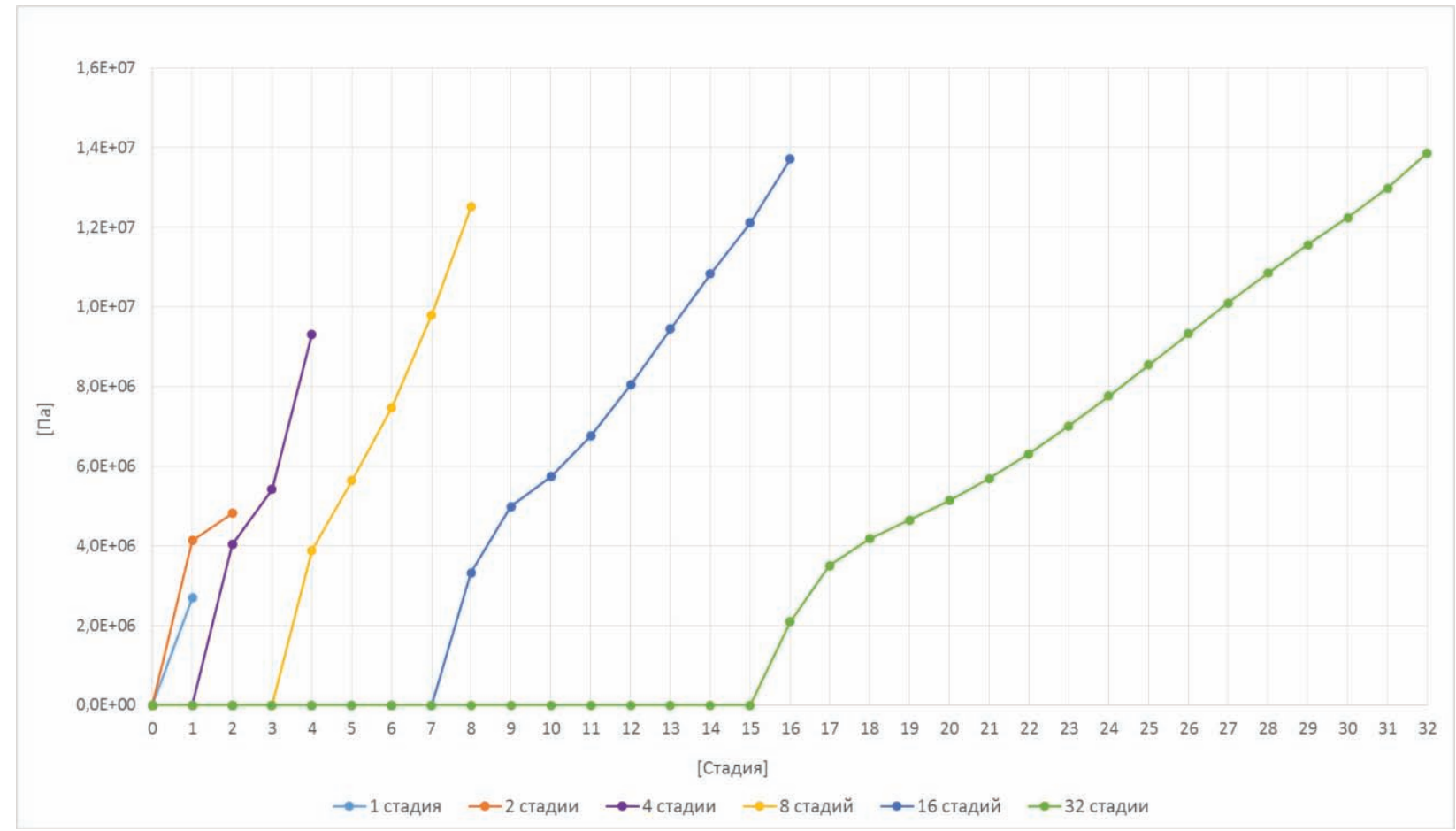

Figure 6. The maximum equivalent stresses according to the IV strength theory (von Mises) of 16 ring of the shell.

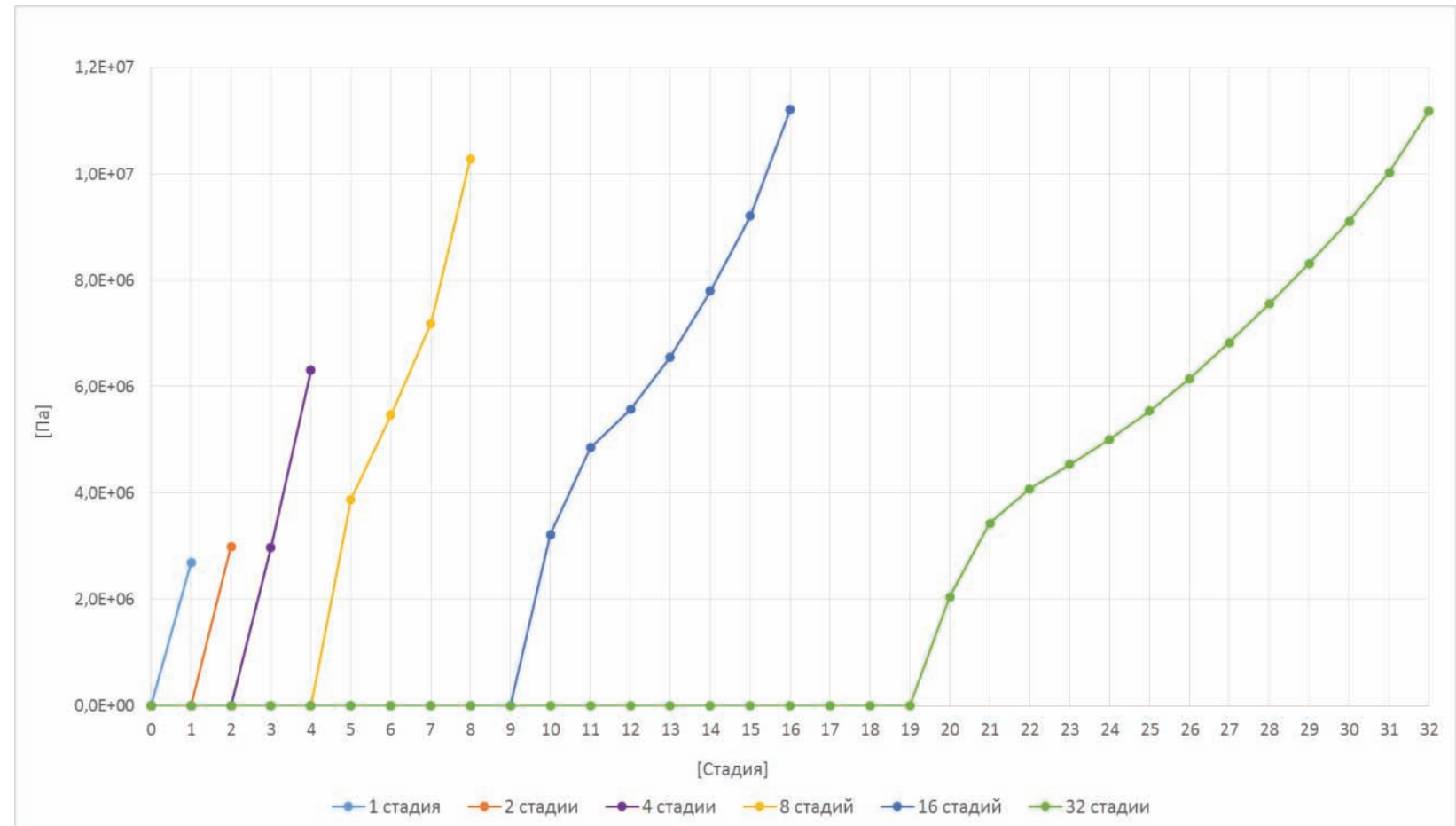

Figure 7. The maximum equivalent stresses according to the IV strength theory (von Mises) of 20 ring of the shell. 


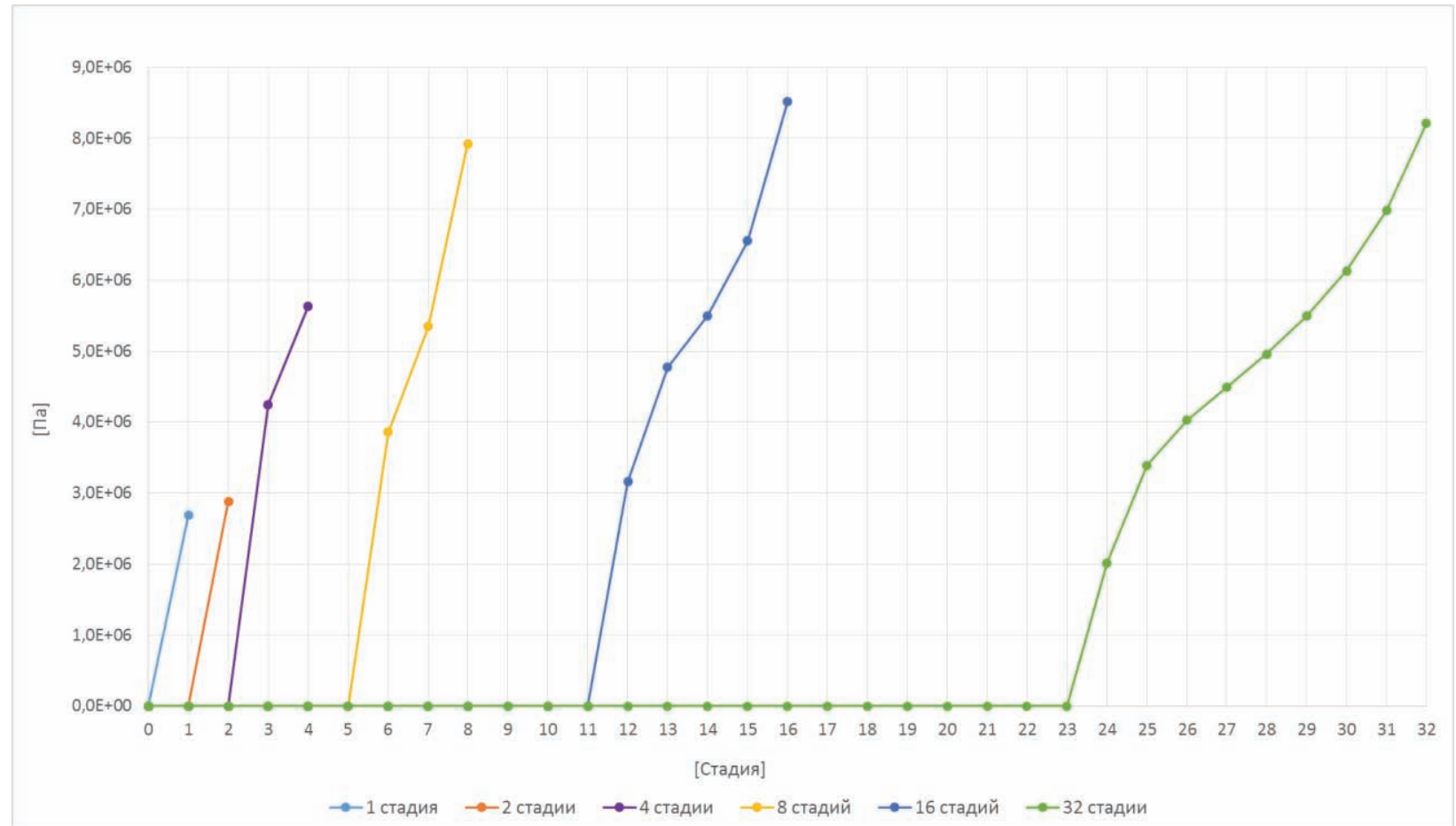

Figure 8. The maximum equivalent stresses according to the IV strength theory (von Mises) of 24 ring of the shell.

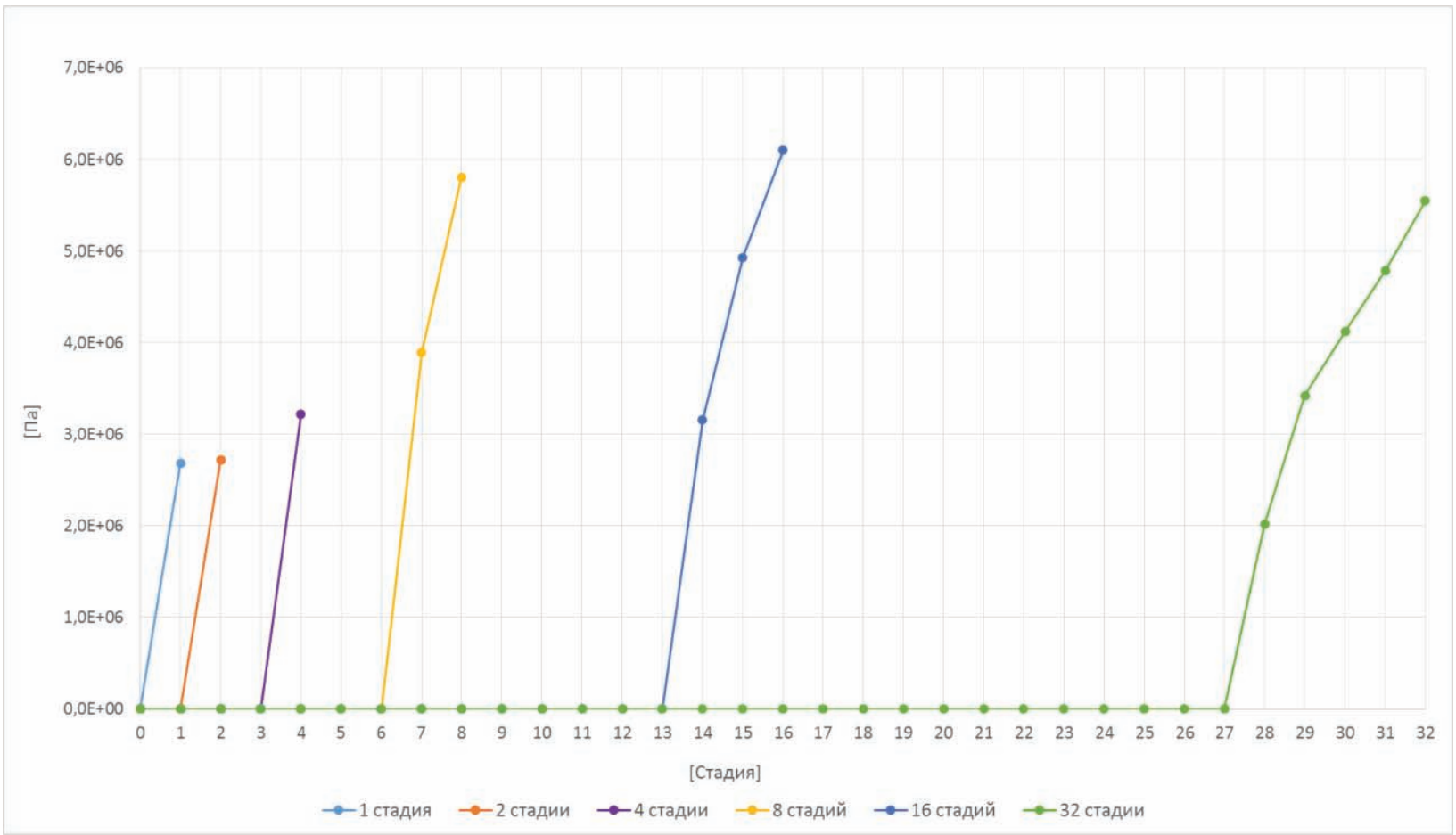

Figure 9. The maximum equivalent stresses according to the IV strength theory (von Mises) of 28 ring of the shell. 


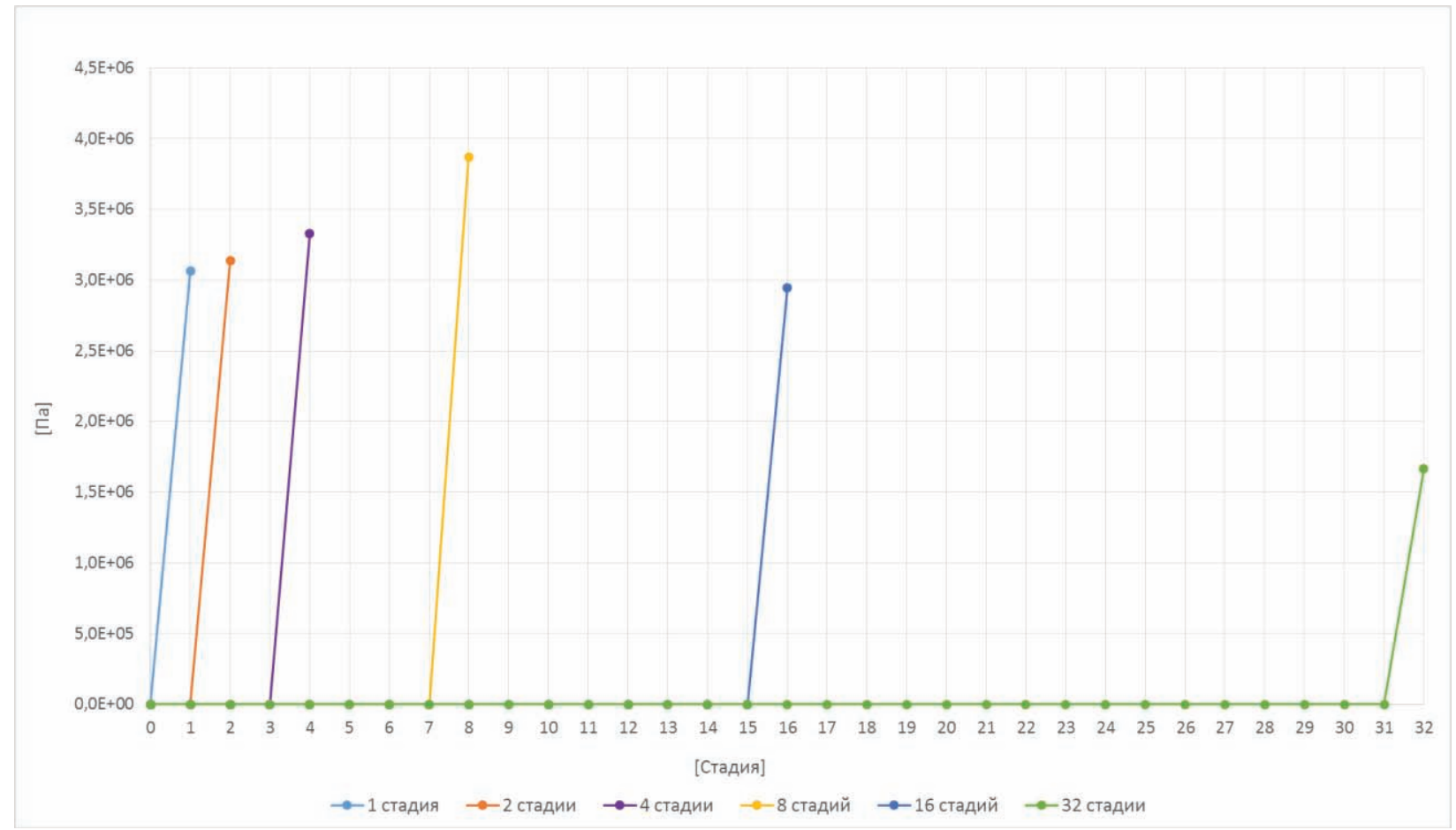

Figure 10. The maximum equivalent stresses according to the IV strength theory (von Mises) of 32 ring of the shell.

This is due to the first ring of the shell (or the first two or the first four rings, depending on the design case) starts to work before the others. The first ring takes most of the loads from the soil massif and the added rings. In the case of the last ring of the shell, conversely, a significant part of the soil massif loads is already redistributed to the activated rings of the shell, so the last ring takes a smaller part of the loads.

It should also be noted that all considered shell rings, except the last one, have significantly underestimated stresses in the design cases, which have less than 8 stages. This is due to the fact that in these cases all the shell rings or a large number of rings are activated in one stage. Therefore, the load from the soil massif is redistributed evenly and there are no residual stresses in the shell rings from the previous stages of calculation.

In Figure 11 are shown the distribution of the maximum equivalent stresses according to the IV strength theory (von Mises) in the shell rings of the design case with 32 stages. The maximum stress values are at the bottom of the shell ring, the minimum stress values are at the sides of the shell.
In table 1 is shown the difference in the percentage of the maximum equivalent stresses according to the IV strength theory (von Mises) $[12,13]$ in the shell rings of all design cases compared to the stresses obtained in the design case with 32 stages.

\section{CONCLUSION}

The authors consider how the construction stages affect the stress-strain state of the tunnel shell and the soil massif using numerical methods. The volumetric design model of the tunnel shell and the soil massif is made. The calculation consists of several stages from the beginning of the tunnel shell construction to the end of the work.

The results showed that the account of the construction stages in the design model significantly affects the stress-strain state of the shell and the soil massif. In design cases, which have less than 8 stages, the maximum equivalent stresses according to the IV strength theory (von Mises) in the vast majority of shell rings are significantly underestimated. 
01

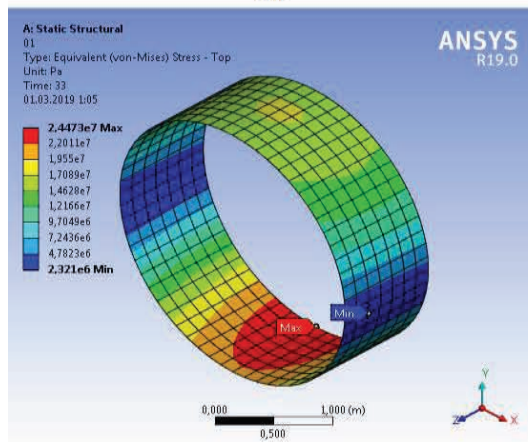

12

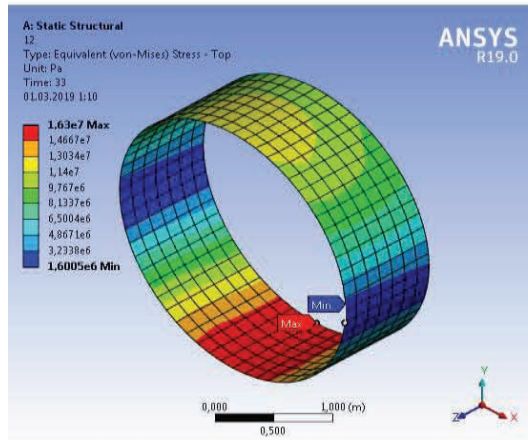

24

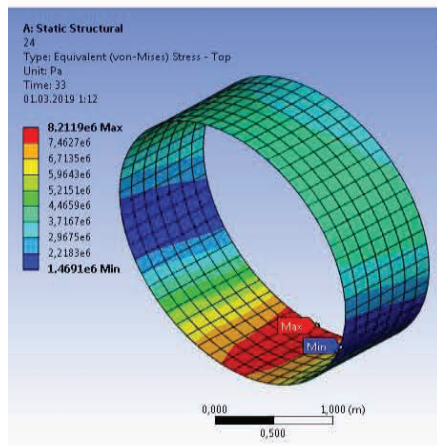

04

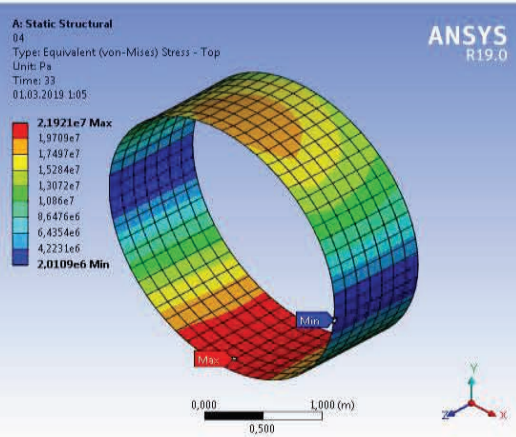

16

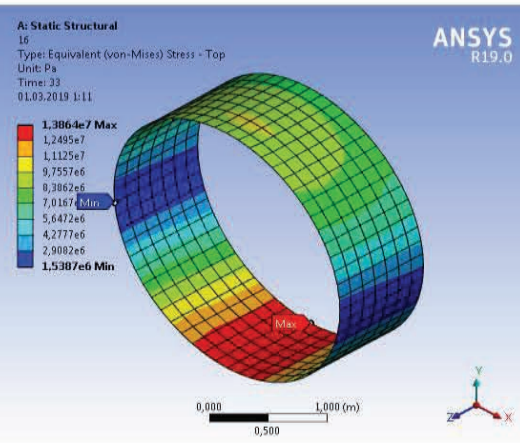

28

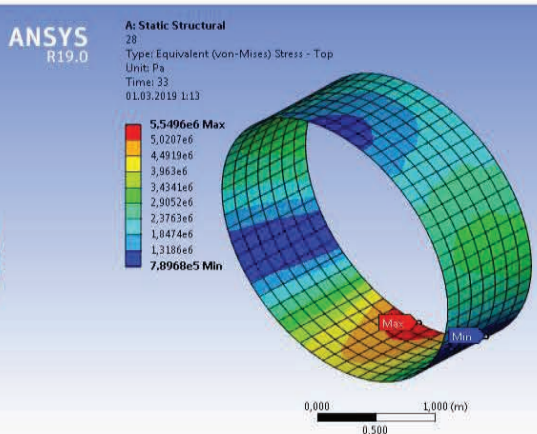

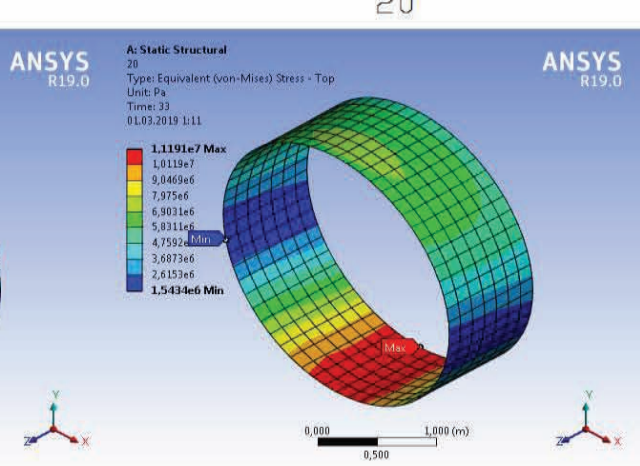

08

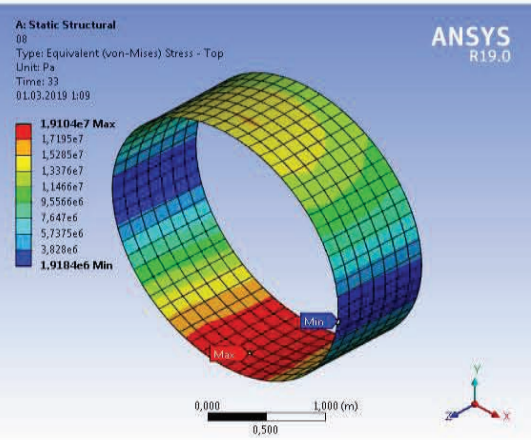

20

32

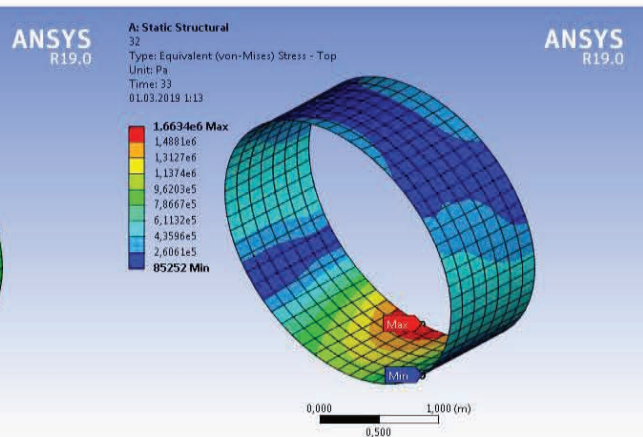

Figure 11. The distribution of the maximum equivalent stresses according to the IV strength theory (von Mises) in the shell rings of the design case with 32 stages.

Table 1. The difference in the percentage of the maximum equivalent stresses according to the IV strength theory (von Mises).

\begin{tabular}{|c|c|c|c|c|c|}
\hline Shell ring & 1 stage & 2 stages & 4 stages & 8 stages & 16 stages \\
\hline 1 & $682,2 \%$ & $334,6 \%$ & $84,0 \%$ & $26,7 \%$ & $9,4 \%$ \\
\hline 4 & $713,9 \%$ & $291,6 \%$ & $65,7 \%$ & $12,3 \%$ & $3,3 \%$ \\
\hline 8 & $610,7 \%$ & $240,5 \%$ & $48,6 \%$ & $12,7 \%$ & $2,8 \%$ \\
\hline 12 & $506,5 \%$ & $199,8 \%$ & $65,7 \%$ & $11,4 \%$ & $1,6 \%$ \\
\hline 16 & $415,8 \%$ & $187,6 \%$ & $48,8 \%$ & $10,8 \%$ & $1,1 \%$ \\
\hline 20 & $316,3 \%$ & $273,5 \%$ & $77,4 \%$ & $8,8 \%$ & $-0,3 \%$ \\
\hline 24 & $205,6 \%$ & $184,9 \%$ & $45,7 \%$ & $3,7 \%$ & $-3,6 \%$ \\
\hline 28 & $106,7 \%$ & $104,0 \%$ & $72,3 \%$ & $-4,4 \%$ & $-9,0 \%$ \\
\hline 32 & $-45,7 \%$ & $-46,9 \%$ & $-50,0 \%$ & $-57,0 \%$ & $-43,6 \%$ \\
\hline
\end{tabular}


This is due to the fact that in these cases all the shell rings or a large number of rings are activated in one stage. Therefore, the load from the soil massif is redistributed evenly and there are no residual stresses in the shell rings from the previous stages of calculation.

Therefore, on account of the results obtained from the six design cases of the volumetric model taking into account the construction stages, the authors recommend in practical calculations to take 8 or more stages of the shell construction. It is permissible to take no more than 8 stages due to the complexity and time costs of calculations. However, it is worth noting that in the first and last rings of the shell the maximum equivalent stresses will be underestimated and overstated respectively.

The results showed that the account of the construction stages in the design model significantly affects the stress-strain state of the shell and the soil massif. In design cases, which have less than 8 stages, the maximum equivalent stresses according to the IV strength theory (von Mises) in the vast majority of shell rings are significantly underestimated. This is due to the fact that in these cases all the shell rings or a large number of rings are activated in one stage. Therefore, the load from the soil massif is redistributed evenly and there are no residual stresses in the shell rings from the previous stages of calculation.

Therefore, on account of the results obtained from the six design cases of the volumetric model taking into account the construction stages, the authors recommend in practical calculations to take 8 or more stages of the shell construction. It is permissible to take no more than 8 stages due to the complexity and time costs of calculations. However, it is worth noting that in the first and last rings of the shell the maximum equivalent stresses will be underestimated and overstated respectively.

\section{REFERENCES}

1. Alexandrov A.V., Potapov V.D. Osnovy teorii uprugosti i plastichnosti [Foundations of the theory of elasticity and plasticity]. Moscow, High school, 1990, 400 pages (in Russian).

2. Bate K., Wilson E. Chislennye metody analiza i metod konechnyh jelementov [Numerical analysis methods and finite element method]. Moscow, Stroizdat, 1982, 446 pages (in Russian).

3. Gallagher R. Metod konechnyh jelementov. Osnovy [The finite element method. Basics]. Moscow, Mir, 1984. 429 pages (in Russian).

4. Kositsyn S.B., Dolotkazin D.B. Raschet sterzhnevyh sistem, vzaimodejstvujushhih s uprugim osnovaniem, metodom konechnyh jelementov $\quad \mathrm{s} \quad$ ispol'zovaniem programmnogo kompleksa MSC/NASTRAN FOR WINDOWS [Calculation of beam systems interacting with an elastic foundation by finite element method using the software complex MSC/NASTRAN FOR WINDOWS]. Moscow, MIIT, 2004, 116 pages (in Russian).

5. Kositsyn S.B., Tran Xuan Linh. Chislennyj analiz naprjazhennodeformirovannogo sostojanija ortogonal'no peresekajushhihsja cilindricheskih obolochek bez ucheta i s uchetom ih odnostoronnego vzaimodejstvija s okruzhajushhim massivom grunta [Numerical analysis of stress - strain state of orthogonal intersecting cylindrical shells with and without taking into account their unilateral interaction with the surrounding soil]. // International Journal for Computational Civil and Structural Engineering, 2014, Volume 10, Issue 1, pp. 72-78 (in Russian).

6. Perelmuter A.V., Slivker V.I. Raschetnye modeli sooruzhenij i vozmozhnosti ih analiza [Design models of structures and possibilities of their analysis]. Kiev, Steel, 2002, 445 pages (in Russian).

7. Prevo R. Raschet na prochnost' truboprovodov zalozhennyh V grunt [Strength calculation of pipelines laid in the 
ground]. Moscow, Stroyizdat, 1964, 123 pages (in Russian).

8. Strang G., Fix J. Teorija metoda konechnyh jelementov [Theory of the finite element method]. Moscow, Mir, 1977, 349 pages (in Russian).

9. Shaposhnikov N.N. Raschet krugovyh tonnel'nyh obdelok na uprugom osnovanii, harakterizuemom dvumja kojefficientami posteli [Calculation of circular tunnel linings in elastic foundation characterized by the two coefficients of elastic foundation]. // Scientific Proc. of Moscow state university of railway engineering, 1961, Issue 131, pp. 296-305 (in Russian).

10. Attewell P.B. Ground movements caused by tunnelling in soil. Large ground movements and structures. London, Pentech Press, 1978, pp. 120-140.

11. Attewell P.B., Woodman J.P. Predicting the dynamics of ground settlement and its derivatives caused by tunneling in soil. // Ground Engineering, 1982, pp. 75-83.

12. Broms B.B., Bennermark H. Stability of clay in vertical openings. // Journal of Soil Mechanics and Foundations, ASCE, 1967, 193 pages.

13. Zienkiewicz O.C., Taylor R.L. The finite element method. Volume 2: Solid mechanics. Butterworth-Heinemann, 2000, 479 pages.

\section{СПИСОК ЛИТЕРАТУРЫ}

1. Александров А.В., Потапов В.Д. Основы теории упругости и пластичности. - М.: Высшая школа, 1990. - 400 c.

2. Бате К., Вилсон Е. Численные методы анализа и метод конечных элементов. М.: Стройиздат, 1982. - 446 с.

3. Галлагер Р. Метод конечных элементов. Основы. - М.: Мир, 1984. - 429 с.

4. Косицын С.Б., Долотказин Д.Б. Расчет стержневых систем, взаимодействующих с упругим основанием, методом конечных элементов с использованием программного комплекса

MSC/NASTRAN FOR WINDOWS. - M.: МИИТ, 2004 - 116 c.

5. Косицын С.Б., Чан Суан Линь. Численный анализ напряженнодеформированного состояния ортогонально пересекающихся цилиндрических оболочек без учета и с учетом их одностороннего взаимодействия с окружающим массивом грунта. // International Journal for Computational Civil and Structural Engineering, 2014, Volume 10, Issue 1, pp. 72-78.

6. Перельмутер А.В., Сливкер В.И. Расчетные модели сооружений и возможности их анализа. - Киев: Сталь, 2002. -445 c.

7. Прево Р. Расчет на прочность трубопроводов заложенных в грунт. М.: Стройиздат, 1964. - 123 с.

8. Стренг Г., Фикс Дж. Теория метода конечных элементов. - М.: Мир, 1977, $349 \mathrm{c}$.

9. Шапошников Н.Н. Расчет круговых тоннельных обделок на упругом основании, характеризуемом двумя коэффициентами постели. // Научн. тр. Московского института инженеров железнодорожного транспорта, 1961, Вып. 131, с. 296-305.

10. Attewell P.B. Ground movements caused by tunnelling in soil. Large ground movements and structures. London, Pentech Press, 1978, pp. 120-140.

11. Attewell P.B., Woodman J.P. Predicting the dynamics of ground settlement and its derivatives caused by tunneling in soil. // Ground Engineering, 1982, pp. 75-83.

12. Broms B.B., Bennermark H. Stability of clay in vertical openings. // Journal of Soil Mechanics and Foundations, ASCE, 1967, 193 pages.

13. Zienkiewicz O.C., Taylor R.L. The finite element method. Volume 2: Solid 
Numerical Analysis of the Account of the Stages in the Calculation of the Shell Together with the Soil Massif

mechanics. Butterworth-Heinemann, 2000, 479 pages.

Sergey B. Kosytsyn, Advisor of the Russian Academy of Architecture and Construction Sciences (RAASN), Dr. Sc., Professor, Head of Department of Theoretical Mechanics, Russian University of Transport (MIIT); 9b9, Obrazcova Street, Moscow, 127994, Russia;

phone/fax: +7(499) 978-16-73;

E-mail: kositsyn-s@yandex.ru, kositsyn-s@mail.ru.

Vladimir Y. Akulich, PhD student of Department of Theoretical Mechanics, Russian University of Transport (MIIT); 9b9, Obrazcova Street, Moscow, 127994, Russia; phone/fax: +7(499) 978-16-73;

E-mail: 79859670635@yandex.ru.

Косицын Сергей Борисович, советник РААСН, доктор технических наук, профессор; заведующий кафедрой «Теоретическая механика», Российский университет транспорта (МИИТ); 127994, Россия, г. Москва, ул. Образцова, 9, стр. 9; тел./факс +7(499) 978-16-73;

E-mail: kositsyn-s@yandex.ru, kositsyn-s@mail.ru

Акулич Владимир Юрьевич, аспирант кафедры «Теоретическая механика», Российский университет транспорта (МИИТ); 127994, Россия, г. Москва, ул. Образцова, 9, стр. 9; тел./факс +7(499) 978-16-73;

E-mail: 79859670635@yandex.ru. 